\title{
The Distressed State of Primary Care in Virginia Pre-Medicaid Expansion and Pre-Pandemic
}

\author{
E. Marshall Brooks, PhD, Alison Huffstetler, MD, Jacqueline Britz, MD, MSPH, \\ Benjamin Webel, BS, Paulette Lail Kashiri, MPH, Alicia Richards, BS, Roy Sabo, PhD, \\ Kristen O'Loughlin, MS, MA, Peter Cunningham, PhD, Andrew Barnes, PhD, \\ Tony Kuzel, MD, MHPE, and Alex H. Krist, MD, MPH
}

Background: Primary care is crucial to the health of individuals and communities, but it faces numerous structural and systemic challenges. Our study assessed the state of primary care in Virginia to prepare for Medicaid expansion. It also provides insight into the frontline of health care prior to an unprecedented global COVID-19 pandemic.

Methods: We surveyed $\mathbf{1 6 2 2}$ primary care practices to understand organizational characteristics, scope of care, capacity, and organizational stress.

Results: Practices (484) varied in type, ownership, location, and care for medically underserved and diverse patient populations. Most practices accepted uninsured and Medicaid patients. Practices reported a broad scope of care, including offering behavioral health and medication-assisted therapy for opioid addiction. Over half addressed social needs like transportation and unstable housing. One in three practices experienced a significant stress in 2019, prepandemic, and only $18.8 \%$ of practices anticipated a stress in 2020.

Conclusions: Primary care serves as the foundation of our health care system and is an essential service, but it is severely stressed, under-resourced, and overburdened in the best of times. Primary care needs strategic workforce planning, adequate access to resources, and financial investment to sustain its value and innovation. (J Am Board Fam Med 2021;34:1189-1202.)

Keywords: COVID-19, Family Medicine, Health Policy, Medicaid, Medically Underserved Area, Primary Health Care, Research Report, Surveys and Questionnaires, Virginia, Workforce

\section{Introduction}

Primary care plays a critical role in promoting the health of individuals and communities. The provision of primary care has been shown to decrease mortality, improve health outcomes, promote equity, and more efficiently use limited health care

This article was externally peer reviewed.

Submitted 2 February 2021; revised 7 June 2021; accepted 21 July 2021.

From the Department of Family Medicine and Population Health, Virginia Commonwealth University, Richmond, VA (EMB, AH, JB, BW, PLK, AR, RS, KO, TK, AHK); Department of Biostatistics, Virginia Commonwealth University, Richmond, VA (AR, RS); Department of Health Behavior and Policy, Virginia Commonwealth University, Richmond, VA (PC, AB); Department of Psychology, Virginia Commonwealth University, Richmond. VA (KO).

Funding: Funding for this study was provided by the Department of Medical Assistance Services and the National Center for Advancing Translational Sciences (UL1TR002649). The opinions expressed in this manuscript are those of the authors and do not necessarily reflect those of the funders. resources. ${ }^{1-3}$ Patients with a usual source of primary care are healthier and are more likely to receive recommended care. In the United States, more than $35 \%$ of health care visits are to primary care clinicians, ${ }^{4}$ who can address the spectrum of health needs including prevention, chronic disease management, acute care, and behavioral health. Primary care clinicians can serve as an entry point to health care, as well as provide continuous, coordinated, and comprehensive care for patients and

Conflict of interest: The authors of this manuscript have no conflicts of interest to disclose, beyond being primary care clinicians and researchers.

Disclaimer: Dr. Krist is a member of the US Preventive Services Task Force (USPSTF). The findings and conclusions in this document do not necessarily represent the views of the USPSTF. No statement in this manuscript should be construed as an official position of the USPSTF.

Corresponding author: Alex Krist, MD, MPH, One Capital Square Room 631, 830 East Main St, Richmond, VA 23219 (E-mail: ahkrist@vcu.edu). 
populations. ${ }^{5}$ Given its value and broad reach, high-quality primary care can be an essential force for promoting health equity.

Despite our need for high-quality primary care, we only have a superficial understanding of the state of primary care. Compared with other developed countries, the United States has an inadequate supply of primary care providers. ${ }^{6}$ Students increasingly chose to pursue more lucrative specialty careers. Primary care is under-resourced, receiving only 5\% of health care expenditures, requiring practices to do more with less. ${ }^{4}$ While licensure data can be used to identify primary care clinicians, it is more difficult to identify primary care practices. As a result, less is known about the distribution and location of primary care practices, practice composition of clinicians and staff, services provided, ownership and organizational structure, and stress and stability. Understanding these factors is essential to ensure primary care design broadly meets the needs of communities.

In January 2019, Virginia became the 33rd state to expand Medicaid coverage. The state anticipated up to 500,000 previously uninsured residents with family incomes less than or equal to $138 \%$ of the federal poverty line becoming insured. To determine whether primary care practices could meet the new demand for care, we sought to evaluate the current state, capacity, and stresses of Virginia's primary care practices. Virginia, which is in the 50th percentile nationally for the overall size and makeup of primary care, ${ }^{7,8}$ may be generalizable to other settings as well for understanding the state of primary care nationally.

\section{Methods}

We queried the 2018 Virginia Department of Health Professions (VDHP) licensure data and the 2016 Virginia All Payer Claims (APCD) to identify all active primary care clinicians and their practices in the state. ${ }^{9,10}$ Between October 2018 and March 2019, we surveyed every identified primary care practice to understand their characteristics, affiliations, scope of care, patient accessibility, and the system pressures and stresses they face. The Virginia Commonwealth University Institutional Review Board deemed this not human subjects research.

\section{Primary Care Practice Identification}

We sought to identify all adult primary care practices including family medicine, general internal medicine, preventive medicine, and geriatric practices. Since the overarching goal of our study is to understand primary care practice capacity for Medicaid expansion, we excluded pediatric practices as all children in Virginia were already eligible for Medicaid. We also excluded obstetric and gynecologic practices because we were not able to determine which practices provided primary versus specialty care.

To identify primary care practices, we followed a 6-step process. First, we identified primary care clinicians and their practice from the VDHP licensure files by self-designated specialty type and practice name and address. ${ }^{11}$ Second, we manually reviewed practice names and excluded all those appearing to be specialty practices. For example, a self-designated primary care clinician in a practice with "cardiology care" in its name would be excluded. Third, we queried the APCD and removed clinicians with no claims, assuming they represented retired or nonpracticing clinicians. ${ }^{9}$ Fourth, we identified all clinicians with 50 or more claims in the APCD that were not in the VDHP licensure file $(\mathrm{n}=715)$ and manually conducted internet searches to determine if they were a primary care clinician and if their practice was in Virginia.

Fifth, from the VDHP and APCD we assembled a comprehensive list of practice names and addresses. As the VDHP data were self-reported, there was some variation in how clinicians listed the same practice. By cross querying listed practice name and listed address and manually reviewing content, the list was refined. For example, we verified whether 2 clinicians that shared the same address but listed their practice name slightly differently actually practiced in the same or different practices using internet queries. Practice name was identified from the VHDP. Since nearly a third of clinicians did not report a practice affiliation, we identified those practice affiliations by internet searches and local connections within our state's practice-based research network, the Virginia Ambulatory Care Outcomes Research Network (ACORN). Clinicians who could not be matched or found through internet queries were excluded from the analyses. Finally, our practice list was further refined based on our survey responses, described below.

\section{Practice Survey}

The practice survey questions were drawn from several sources. Questions were selected based on information needs and experiences from the Department of Medical Assistance Services (DMAS) and 
ACORN. Questions from the annual ACORN practice inventory assessed practice size, affiliations, population served, panel size, patients seen per day, and services offered; questions have been used in ACORN surveys of practices for the past decade and were developed from the VDHP licensure questions, American Board of Family Medicine Graduate Survey, American Association of Medical Colleges (AAMC) Physician Survey of Primary Care, and assessments of the patient-centered medical home. ${ }^{12-}$ ${ }^{14}$ Questions from the Healthy Michigan Plan's physician survey assessed a practice's clinician capacity, payer mix, practice environments, strategies to provide access to care, intent to see more Medicaid beneficiaries, and barriers to caring for Medicaid beneficiaries. ${ }^{15}$ Questions were drawn or adapted from additional studies to assess how practices addressed unhealthy behaviors, mental health, and social needs; major changes the practice experienced or anticipated; and the perceived competitiveness of the market. ${ }^{16-18}$ We considered experienced or anticipated major practice changes and competitiveness of the local market as surrogates for practice stress. See Appendix for the full survey instrument.

Using the identified addresses and e-mails, practice surveys were mailed, faxed, or e-mailed to all primary care practices in Virginia. When possible, invitations were directed to a known senior practice clinician or administrator. The survey included a cover letter from the Virginia secretary of health to explain the purpose and importance of the survey. Practices were reminded up to 6 times to complete the survey, including telephone reminders to nonresponders. In addition, the Virginia Academy of Family Physicians, Virginia Chapter of the American College of Physicians, Medical Society of Virginia, and ACORN e-mailed all their primary care members an electronic survey for completion, asking them to identify a practice lead to complete the survey, referencing that they may have already received and completed a survey, and asking each practice to only complete the survey once. If we received duplicate surveys for a practice, we only included the first survey response in our analysis.

\section{Statistical Analysis}

Our unit of analysis was the primary care practice. We provided descriptive summaries such as percentages, counts, and means based on practice survey responses. We geocoded all primary care practices' addresses. A $\chi^{2}$ goodness-of-fit test was used to compare the geographical distribution of practice survey respondents to that of all practices, using ZCTA as the unit of analysis. SAS version 9.4 (Cary, NC) was used for analyses and geocoding.

\section{Results}

Overall, 484 practices of 1622 completed the survey (29.8\% response rate). Survey respondents were representative of primary care practices serving adults throughout Virginia. The geographical distribution of respondents was similar to that of all primary care clinicians (Figure 1), which was supported by a goodness-of-fit test ( $\chi^{2}$ teststatistic $=0.4, \mathrm{df}=228, P$ value $=0.999)$.

Practices varied in type, ownership, location, and certifications (see Table 1). Practices were primarily clinician owned $(53.4 \%)$, followed by health system owned (25.1\%). A majority were either part of a medical group $(39.7 \%)$ or health system $(27.9 \%)$. Over a third had patient-centered medical home recognition $(34.3 \%)$ and half were part of an accountable care organization $(50.2 \%)$. Practices on average had 4.5 clinicians and 1.7 care team member full time equivalents (FTEs). Care team members included behavioral health care providers, social workers, and case managers.

\section{Populations Served}

Practices reported caring for diverse patient populations that generally reflected the commonwealth's demographics (Table 1). ${ }^{21}$ Practices reported caring for a slightly greater proportion of racial/ethnic minority patients than the proportion that reside in Virginia, estimating their practice population to be 64.4\% White, 24.5\% Black, 8.3\% Asian or Pacific Islander, 2.8\% Native American or Alaska Native, and $11.1 \%$ Hispanic/Latino. An average of $41.4 \%$ of practices reported having at least 1 clinician who can deliver care in a language other than English.

Practices also reported caring for high proportions of medically underserved populations (Table 1). Practices reported a payer mix of $10.2 \%$ uninsured, 11.9\% Medicaid, 29.4\% Medicare, and 48.2\% commercial or private insurance. Fully $89.7 \%$ of practices reported accepting new uninsured patients, and $87.9 \%$ were accepting new Medicaid patients. A high proportion of practices were located in more historically underserved rural communities (53.0\%), while only $12.1 \%$ of Virginians live in a rural community. ${ }^{22}$ 
Figure 1. A. Primary care practice distribution in Virginia $(n=1622)$. B. Primary care practice survey response distribution in Virginia $(n=484)$.

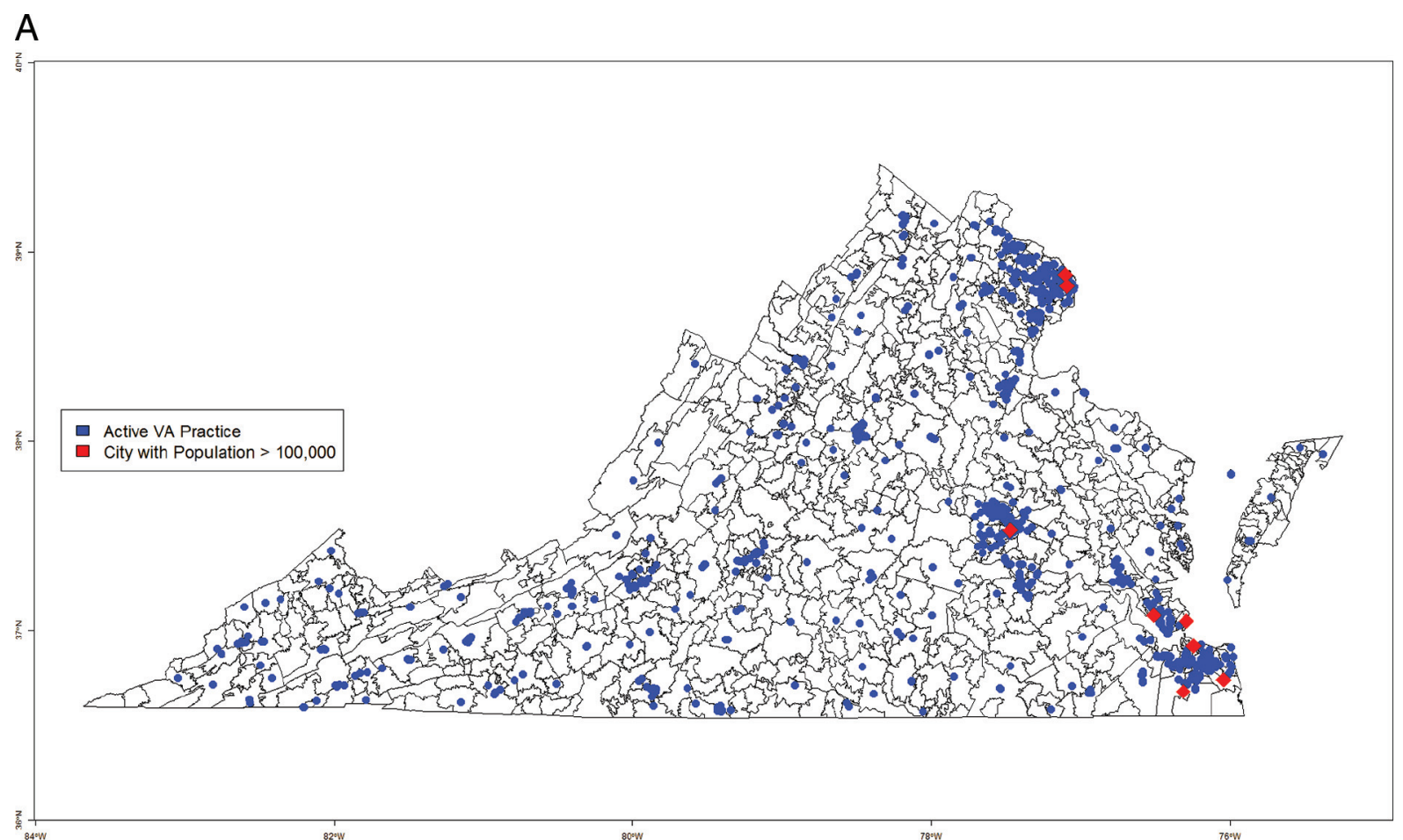

\section{B}

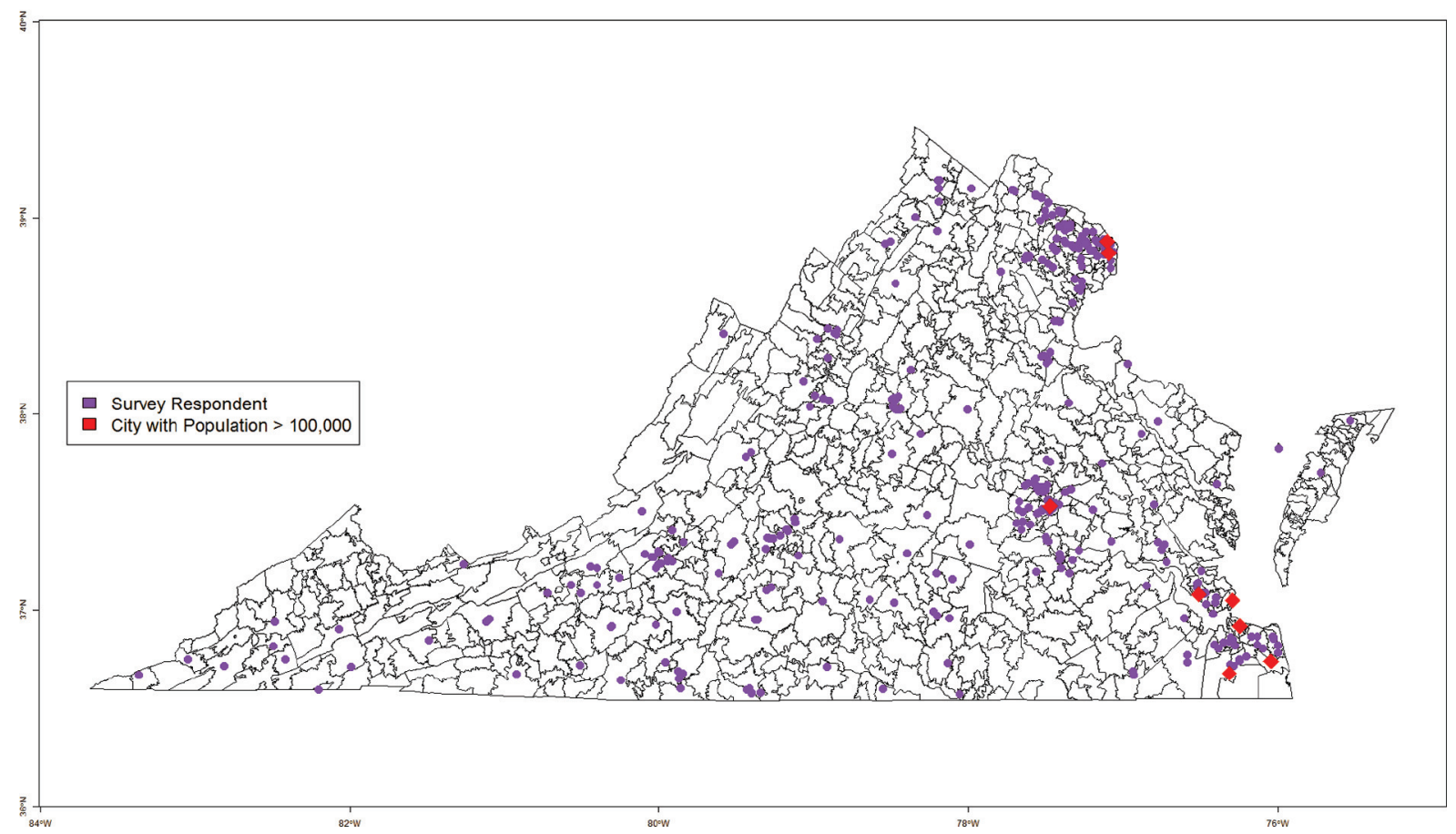

\section{Access to Care and Scope of Practice}

Practices reported multiple strategies to improve access to care (Table 2). Strategies to improve access to care include $89.7 \%$ of practices providing same-day appointments, 42.2\% evening and weekend access, and $67.4 \%$ 24-hour phone access. Furthermore, practices made accessing ancillary services easy, with $70.7 \%$ of practices having onsite laboratory and 
General Practice Characteristics

Practice type

- Sole primary care

$401 / 466(86.1 \%)$

- Primary-specialty mix

$65 / 466(13.9 \%)$

Organization

- Part of a medical group

192/484 (39.7\%)

- Part of a health system

$135 / 484(27.9 \%)$

Ownership

- Hospital/health system

$107 / 427(25.1 \%)$

- Clinician owner

- Clinician partially owned

$228 / 427(53.4 \%)$

$11 / 427(2.6 \%)$

- Private sponsor corporation

$76 / 427(17.8 \%)$

- Insurance company

- University

$0 / 427(0.0 \%)$

$5 / 427(1.2 \%)$

Provides direct primary care

- Yes, for all patients

$52 / 461(11.3 \%)$

- Yes, for some patients

$28 / 461(6.1 \%)$

- No

$381 / 461(82.7 \%)$

Additional characteristics

$157 / 458(34.3 \%)$

- Has patient-centered medical bome recognition

$226 / 450(50.2 \%)$

- Part of an accountable care organization

$85 / 479(17.8 \%)$

- Urban

$140 / 479(29.2 \%)$

- Suburban

$254 / 479(53.0 \%)$

Practice Clinicians

Mean (range) of practice clinician full=time equivalent (FTE)

- Family medicine physicians

- Internal medicine physicians

- Pediatricians $^{\dagger}$

- Nurse practitioners

- Physician assistants

Mean (range) of total practice provider FTE per practice

Average (range) of practice care team member FTE

- Psychiatrist or psychiatric nurse practitioner

- Psychologist

- Social worker

- Case manager or care coordinator

Mean (range) of total care team member FTE per practice

$0.8(0.0$ to 2.0$)$

$1.3(0.5-3.0)$

$1.0(0.1$ to 4.0$)$

$1.2(0$ to 4.0$)$

$1.7(0.1$ to 7.4$)$

Practice Patients

Mean percent of patients seen in practices (and Virginia State mean) ${ }^{\mathrm{c}}$

- White

- African American or Black

$24.5 \%(19.9 \%)$

- Asian or Pacific Islander

$8.3 \%(7.0 \%)$

$2.8 \%(0.5 \%)$

- Native American or Alaska Native

$11.1 \%(9.8 \%)$

$19.9(10.0$ to 40.0$)$

Mean number of (range) patients seen per full day of patient care per provider

$44 / 348(41.4 \%)$

Percent of practices with a provider who can deliver care in a language other than English

Mean estimated payer mix for practices (and Virginia state average) ${ }^{\ddagger}$ 
Table 1. Continued

General Practice Characteristics

- Commercial or private insurance

$48.2 \%(56.0 \%)$

- Medicare

$29.4 \%(18.1 \%)$

- Medicaid

$11.9 \%(16.6 \%)$

- Uninsured

$10.2 \%(9.3 \%)$

Percent of practices accepting new patients with

- Commercial or private insurance

- Medicare

- Medicaid

- Uninsured

Values based on survey responses. Survey mailed to 1622 practices and 484 responded.

*Based on 2010 Census classification of zip. ${ }^{33}$

${ }^{\dagger}$ Practice reported number of pediatricians.

${ }^{\ddagger}$ (Percent) in parentheses represents Virginia state averages based on 2019 Census data. ${ }^{34}$

$30.4 \%$ onsite radiology services. At the time of the survey (ie, prepandemic), $21.1 \%$ offered telehealth services and $11.0 \%$ offered group visits.

Practices reported a broad scope of care beyond the usual primary care domains of acute, chronic, and preventive care (Table 2). Most practices reported some degree of behavioral health including mental health screening (83.7\%), patient handoff to mental health clinicians (52.3\%), and even colocated mental health clinicians (18.2\%). Many practices also address substance abuse disorders, with $80.6 \%$ of practices providing smoking cessation counseling, $65.9 \%$ alcohol misuse treatment, $23.1 \%$ opioid misuse treatment, and $23.1 \%$ medicationassisted therapy for opioids. Many practices even reported efforts to help patients address social needs such as helping patients with out-of-pocket medical expenses $(81.3 \%)$, food insecurity $(52.2 \%)$, transportation (59.5\%), unstable housing (52.2\%), and unemployment (38.9\%).

\section{Practice Stress}

One in 3 practices reported experiencing a significant stress or change in the prior year (see Table 3). Stresses reported by practices included clinician turnover (13.2\%), a major office renovation (11.4\%), adopting a new electronic health record $(8.9 \%)$ or billing system (6.6\%), moving to a new location $(6.0 \%)$, and changing practice ownership (2.7\%). Some practices reported experiencing 2 stresses

Table 2. Primary Care Efforts to Ensure Access to and Comprehensiveness of Care

\begin{tabular}{|c|c|c|c|c|c|}
\hline $\begin{array}{l}\text { Improved Access } \\
\text { to Care }\end{array}$ & $\begin{array}{c}\% \text { Practices with } \\
\text { Feature }\end{array}$ & $\begin{array}{c}\text { Provision of } \\
\text { Behavioral Health }\end{array}$ & $\begin{array}{c}\% \text { Practices Offering } \\
\text { Service }\end{array}$ & $\begin{array}{l}\text { Helping Patients } \\
\text { Address Social Needs }\end{array}$ & $\begin{array}{c}\% \text { Practices } \\
\text { Addressing Need }\end{array}$ \\
\hline $\begin{array}{l}\text { Same-day } \\
\text { appointments }\end{array}$ & $434 / 484(89.7 \%)$ & $\begin{array}{l}\text { Mental health } \\
\text { screening }\end{array}$ & $405 / 484(83.7 \%)$ & Social isolation & $316 / 409(77.3 \%)$ \\
\hline $\begin{array}{l}\text { Evening and } \\
\text { weekend access }\end{array}$ & $204 / 484(42.2 \%)$ & $\begin{array}{l}\text { Communicate with } \\
\text { mental health } \\
\text { providers }\end{array}$ & $282 / 484(56.3 \%)$ & $\begin{array}{l}\text { Intimate partner } \\
\text { violence }\end{array}$ & $337 / 416(81.0 \%)$ \\
\hline $\begin{array}{l}\text { 24-hour phone } \\
\text { service }\end{array}$ & $326 / 484(67.4 \%)$ & $\begin{array}{l}\text { Hand off patients to } \\
\text { mental health } \\
\text { providers }\end{array}$ & $253 / 484(52.3 \%)$ & Food insecurity & $210 / 402(52.2 \%)$ \\
\hline Telehealth visits & $102 / 484(21.1 \%)$ & $\begin{array}{l}\text { Colocated mental } \\
\text { health }\end{array}$ & $88 / 484(18.2 \%)$ & Lack of transportation & $247 / 415(59.5 \%)$ \\
\hline Group visits & $53 / 484(11.0 \%)$ & $\begin{array}{l}\text { Smoking cessation } \\
\text { counseling }\end{array}$ & $390 / 484(80.6 \%)$ & Unstable housing & $213 / 408(52.2 \%)$ \\
\hline Patient portal & $351 / 484(72.5 \%)$ & $\begin{array}{l}\text { Alcohol misuse } \\
\text { treatment }\end{array}$ & $319 / 484(65.9 \%)$ & $\begin{array}{l}\text { Limited health } \\
\text { literacy }\end{array}$ & $303 / 407(74.5 \%)$ \\
\hline $\begin{array}{l}\text { Onsite laboratory } \\
\text { services }\end{array}$ & $342 / 484(70.7 \%)$ & Opioid treatment & $112 / 484(23.1 \%)$ & Unemployment & $159 / 409(38.9 \%)$ \\
\hline $\begin{array}{l}\text { Onsite radiology } \\
\text { service }\end{array}$ & $147 / 484(30.4 \%)$ & $\begin{array}{l}\text { Medication assistance } \\
\text { therapy for opioids }\end{array}$ & $112 / 484(23.1 \%)$ & $\begin{array}{l}\text { Out-of-pocket } \\
\text { medical costs }\end{array}$ & $340 / 418(81.3 \%)$ \\
\hline
\end{tabular}


Table 3. Recent and Anticipated Stresses Experienced by Primary Care Practices

\begin{tabular}{lcc}
\hline Practice Stress & $\begin{array}{c}\text { \% Practices That Experienced } \\
\text { Stress in Previous Year }\end{array}$ & $\begin{array}{c}\text { \% Practices That Anticipate Experiencing } \\
\text { the Stress in Next Year }\end{array}$ \\
\hline Have clinician turnover & $64 / 484(13.2 \%)$ & $25 / 484(5.2 \%)$ \\
Have a major office renovation & $55 / 484(11.4 \%)$ & $34 / 484(7.0 \%)$ \\
Adopt a new electronic medical record system & $43 / 484(8.9 \%)$ & $18 / 484(3.7 \%)$ \\
Adopt a new billing system & $32 / 484(6.6 \%)$ & $15 / 484(3.1 \%)$ \\
Move office to a new location & $29 / 484(6.0 \%)$ & $24 / 484(5.0 \%)$ \\
Change practice ownership & $13 / 484(2.7 \%)$ & $9 / 484(1.9 \%)$ \\
Report any stress & $154 / 484(31.8 \%)$ & $91 / 484(18.8 \%)$
\end{tabular}

(8.9\%), though few reported 3 or more stressors $(0.3 \%)$. Complicating these stressors, $72.7 \%$ of practices reported that their practice environment was somewhat or very competitive.

\section{Discussion}

At the time of our survey (fall 2018 to spring 2019), primary care practices in Virginia were well poised to address the needs of new patients in the runup to Medicaid expansion. Practices had several services and strategies to ensure access to care as well as to address a broad range of traditional health care, health behavior, mental health, and even social needs for Virginians. Practices were distributed throughout the commonwealth, with a high proportion in rural communities that likely otherwise have limited access to health care. Practices also reported caring for higher proportions of racial/ ethnic minority populations, patients with Medicare and Medicaid, and non-English-speaking patients. Most practices reported a willingness to care for new Medicaid beneficiaries and even the uninsured. This collectively demonstrates primary care's essential role in caring for socially and economically marginalized and medically underserved people. $^{19}$

During the COVID-19 pandemic, which disrupted our entire health care delivery system, exacerbated mental health and social needs, and disproportionately harmed and killed the most vulnerable people,$^{20-22}$ primary care was even more necessary and showed its ability to rapidly adapt. To continue to care for patients, primary care practices ramped up existing telehealth systems, implemented new infrastructure, redefined care team member roles, and learned a new way of practicing medicine. ${ }^{23}$ A longitudinal, national, primary care survey, administered since the start of the pandemic, further documented how primary care increased support for mental health (65\% of respondents), increased support for substance abuse $(22 \%$ of respondents), and waived copays and reduced fees $(20 \%) .{ }^{24} \mathrm{We}$ will also be repeating our survey every 2 years to update these findings and document emergent changes and challenges to primary care practices in Virginia in the wake of the pandemic.

Of concern, primary care in Virginia, and likely nationally, is overburdened, under-resourced, and stressed. We found that 1 in 3 practices reported a major change, like new ownership or changing electronic medical records. These changes represent major disruptions that can be expected to strain care delivery and the personal lives of clinicians and staff. Even without these major changes, prior research suggests that primary care suffers from excessive workloads and a high volume of clerical and bureaucratic tasks, documentation mandates, authorizations and preapprovals, and other regulations and mandates. ${ }^{25,26}$ As a result, the norm is for clinicians to work during evenings and weekends to meet these demands. ${ }^{26-28}$ Further, an aging primary care workforce and frequent staff turnover risk creating discontinuities in the institutional knowledge, capacity, and culture of practices. In fact, in our study, $20 \%$ of the primary care clinicians that we identified were over age 65 years and only $12 \%$ were below the age of 40 years.

Not surprisingly, national studies indicate that between a quarter and two thirds of primary care clinicians report being burned out. ${ }^{29-31}$ Rates vary depending on years in practice, gender, and practice and health system leadership. The COVID-19 pandemic and possibly Medicaid expansion in Virginia likely added to this strain and burnout. Nationally, nearly $30 \%$ of those physicians who died from 
COVID-19 were primary care. ${ }^{32}$ During the pandemic, 2 of 3 practices reported that they were experiencing stress at an all-time high. ${ }^{24}$ As a result, $57 \%$ of clinicians in that survey reported a health decline from stress, a fifth of practices reported having clinicians retiring early, nearly half of practices reported furloughing or laying off staff, and 19\% of practices reported a risk of permanently closing.

Our study has 2 key limitations. First, we had a response rate of $30 \%$ for our practice survey. Respondents do seem to be representative of primary care in Virginia with respect to geography, practice type, and patient population, but we cannot assess representativeness in terms of scope of practice or stresses experienced. While we would prefer a higher response rate, we are not aware of any similarly comprehensive statewide survey of primary care. Second, practices self-reported their perception on scope of practice, accessibility, and populations served. Practices may overestimate their scope of practice and service to medically underserved populations. We were able to compare the proportion of practices with Medicare and Medicaid claims with survey responses, and they were generally consistent.

\section{Conclusion}

Primary care is diverse and widespread throughout Virginia. It serves as the foundation of our health care system and is an essential service and public good. Virginia practices are present in every community, have many strategies to enhance access to care, including a wide scope of practice that is necessary to address the root causes for poor health, and are poised to meet the needs of medically underserved people. Despite its necessity and value, primary care reported being severely stressed. Stress is primary care's resting state and is expectantly worse due to the COVID-19 pandemic. The strengths, weaknesses, and points of strain in practices identified here can hopefully be used to inform strategies for reinvesting in primary care. We hope that other states and regions can benefit from doing similar assessments, combining local knowledge with existing data sources. Such an assessment is critical to ensure that primary care can adequately care for our communities.

Other substantial contributions: The authors thank the following students for assisting with data cleaning and formatting, internet searches, mailings, project coordination, and transcript coding: Karina Armenta, David Branson, Tatiana Brown, Kyandra Rivera DeJesus, Jake Giovia, Suha Hafeez, Sarah Owais, Hannah Rak, and Malaika Sohail. We would also like to thank the Virginia Academy of Family Physicians, the Medical Society of Virginia, the Virginia Center for Health Innovation, and the Virginia Department of Health for helping to promote the survey.

To see this article online, please go to: bttp://jabfm.org/content/ 34/6/1189.full.

\section{References}

1. Basu S, Berkowitz SA, Phillips RL, Bitton A, Landon BE, Phillips RS. Association of primary care physician supply with population mortality in the United States, 2005-2015. JAMA Intern Med 2019;179:506-14.

2. Phillips RL, Dodoo MS, Green LA, et al. Usual source of care: an important source of variation in health care spending. Health Aff (Millwood) 2009;28:567-77.

3. Friedberg MW, Hussey PS, Schneider EC. Primary care: a critical review of the evidence on quality and costs of health care. Health Aff (Millwood) 2010;29:766-72.

4. Johansen ME, Kircher SM, Huerta TR. Reexamining the ecology of medical care. N Engl J Med 2016; 374:495-6.

5. Starfield B, Shi L, Macinko J. Contribution of primary care to health systems and health. Milbank Q 2005;83:457-502.

6. Petterson S, McNellis R, Klink K, Meyers D, Bazemore A. The state of primary care in the United States: a chartbook of facts and statistics; 2018. Available from: https://www.graham-center. org/content/dam/rgc/documents/publications-reports/ reports/PrimaryCareChartbook.pdf. Accessed June 2019.

7. Association of American Medical Colleges; 2017. State physician workforce data book. Available from: https://www.aamc.org/data/workforce/reports/ 484392/2017-state-physician-workforce-data-report. html. Accessed June 2019.

8. Petterson SM, Cai A, Moore M, Bazemore A. Virginia: projecting primary care workforce; 2013. Available from: https://www.graham-center.org/ content $/ \mathrm{dam} / \mathrm{rgc} /$ documents/maps-data-tools/statecollections/workforce-projections/Virginia.pdf. Accessed November 2020.

9. Virginia Health Information. All Payer Claims Database. Available from: http://vhi.org/APCD/. Accessed November 2020.

10. Doctor profile data. Available from: http://www. dhp.virginia.gov/downloads/profiledata.asp. Accessed May 2020.

11. Virginia Department of Health Professions. Doctor profile data. Available from: http://www.dhp. virginia.gov/downloads/profiledata.asp. Accessed November 2020. 
12. American Board of Family Medicine; 2019 Graduate survey report. Available from: https:// www.theabfm.org/sites/default/files/PDF/National Only_Report2019.pdf. Accessed November 2020.

13. Stange KC, Nutting PA, Miller WL, et al. Defining and measuring the patient-centered medical home. J Gen Intern Med 2010;25:601-12.

14. Virginia Commonwealth University. Virginia Ambulatory Care Outcomes Research Network (ACORN). Available from: http://acornpbrn.org/. Accessed November 2020.

15. Institute for Healthcare Policy \& Innovation. Healthy Michigan plan evaluation. Available from: https://ihpi.umich.edu/signature-programs/healthymichigan-plan-evaluation. Accessed November 2020.

16. Cohen DJ, Davis M, Balasubramanian BA, et al. Integrating behavioral health and primary care: consulting, coordinating and collaborating among professionals. J Am Board Fam Med 2015;28 Suppl 1:S21-31.

17. Institute of Medicine (US). Capturing social and behavioral domains and measures in electronic health records: phase 2. Washington, DC: National Academies Press, 2015.

18. Donahue KE, Halladay JR, Wise A, et al. Facilitators of transforming primary care: a look under the hood at practice leadership. Ann Fam Med 2013;11 Suppl 1:S27-33.

19. Krist AH, Davidson KW, Ngo-Metzger Q. What evidence do we need before recommending routine screening for social determinants of health? Am Fam Physician 2019;99:602-5.

20. Woolf SH, Chapman DA, Sabo RT, Weinberger DM, Hill L, Taylor DDH. Excess deaths from COVID-19 and other causes, March-July 2020. JAMA 2020;324:1562-4.

21. Do DP, Frank R. Unequal burdens: assessing the determinants of elevated COVID-19 case and death rates in New York City's racial/ethnic minority neighbourhoods. J Epidemiol Community Health 2021;75:321-6.

22. Pierce M, Hope H, Ford T, et al. Mental health before and during the COVID-19 pandemic: a longitudinal probability sample survey of the UK population. Lancet Psychiatry 2020;7:883-92.
23. Krist AH, DeVoe J, Cheng A, Ehrlich T, Jones SM. Redesigning primary care to address the COVID19 pandemic in the midst of the pandemic. Ann Fam Med 2020;18:349-54.

24. Larry A. Green Center. QUICK COVID-19 survey. Available from: https://www.green-center.org/ covid-survey. Accessed November 2020.

25. Baron RJ. What's keeping us so busy in primary care? A snapshot from one practice. N Engl J Med 2010;362:1632-6.

26. Farber J, Siu A, Bloom P. How much time do physicians spend providing care outside of office visits? Ann Intern Med 2007;147:693-8.

27. Gottschalk A, Flocke SA. Time spent in face-toface patient care and work outside the examination room. Ann Fam Med 2005;3:488-93.

28. Arndt BG, Beasley JW, Watkinson MD, et al. Tethered to the EHR: primary care physician workload assessment using EHR event log data and time-motion observations. Ann Fam Med 2017;15: 419-26.

29. Puffer JC, Knight HC, O'Neill TR, et al. Prevalence of burnout in board certified family physicians. J Am Board Fam Med 2017;30:125-6.

30. Shanafelt TD, Gradishar WJ, Kosty M, et al. Burnout and career satisfaction among US oncologists. JCO 2014;32:678-86.

31. Shanafelt TD, Gorringe G, Menaker R, et al. Impact of organizational leadership on physician burnout and satisfaction. Mayo Clin Proc 2015;90:432-40.

32. Gouda D, Singh PM, Gouda P, Goudra B. The demography of deaths in healthcare workers-an overview of 1004 reported COVID-19 deaths. J Am Board Fam Med. In press.

33. United States Census Bureau. 2010 census urban and rural classification and urban area criteria. Available from: https://www.census.gov/programssurveys/geography/guidance/geo-areas/urban-rural/ 2010-urban-rural.html. Accessed November 2020.

34. United States Census Bureau. QuickFacts Virginia; 2019. Available from: https://www.census.gov/quickfacts/ VA. Accessed November 2020. 


\section{Medicaid Expansion Survey}

Thank you for taking the time to complete this survey. It will greatly help in planning for Medicaid Expansion and to improve the care of patients throughout Virginia. The survey has seven sections and will take about 15 minutes to complete.

\section{Section 1: Contact Information}

Practice Name

Medical group name (if applicable)

Health system name (if applicable)

Practice Address

Practice City Practice State Practice Zip Code

\section{Best Point of Contact}

Full Name:

Contact's role:

$\square$ Office Manager
$\square$ Administrative personnel
$\square$ Clinician
$\square$ Nurse
$\square$ Other, please specify:

Preferred method of communication:

$$
\begin{array}{|l}
\square \text { Mail } \\
\hline \square \text { Email } \\
\hline \square \text { Phone }
\end{array}
$$

Contact's phone number:

Contact's email address:

\section{Section 2: Practice Characteristics}

2a. Is your practice primarily a...

$\square$ Primary care practice

$\square$ specialty practice

Mixed primary care and specialty practice

$2 \mathrm{~b}$. Is your practice recognized as a Patient Centered Medical Home (PCMH)?

$\square_{\text {Yes }}$

2c. Is your practice part of an Accountable Care Organization (ACO)?

$$
\square \text { Yes }
$$

2d. Does your practice provide Direct Primary Care (DPC) or charge your patients a monthly or membership fee? $\square$ Yes, for all patients

Yes, for some patients

$\square$ No

2e. Please provide the total number and full time equivalent (FTE) for each clinician type.

\begin{tabular}{|l|c|c|}
\hline & $\begin{array}{c}\text { Total } \\
\text { Number }\end{array}$ & $\begin{array}{c}\text { Total } \\
\text { FTE }\end{array}$ \\
\hline Family Medicine Physician & & \\
\hline Internal Medicine Physician & & \\
\hline Pediatrician & & \\
\hline Nurse Practitioner (NP) & & \\
\hline Physician Assistant (PA) & & \\
\hline
\end{tabular}

2f. Please provide the total number and full time equivalent (FTE) for each integrated or co-located ancillary staff type.

\begin{tabular}{|l|c|c|}
\hline & $\begin{array}{c}\text { Total } \\
\text { Number }\end{array}$ & $\begin{array}{c}\text { Total } \\
\text { FTE }\end{array}$ \\
\hline Psychiatrist or Psychiatric & & \\
Nurse Practitioner & & \\
\hline Psychologist & & \\
\hline Licensed Clinical Social & & \\
Worker (LCSW) or Licensed & & \\
Professional Counselor (LPC) & & \\
\hline $\begin{array}{l}\text { Case Manager, Care } \\
\text { Coordinator, or Patient }\end{array}$ & & \\
Navigator & & \\
\hline
\end{tabular}


$2 \mathrm{~g}$. Please provide your best estimate for how many patients, on average, a clinician in your practice sees in full day of patient care.

$2 \mathrm{~h}$. Please provide your best estimate for what percentage of your patients belong to each of the following groups.

\begin{tabular}{|l|l|}
\hline & Percent (\%) \\
\hline African-American or Black & \\
\hline Hispanic or Latino & \\
\hline Asian or Pacific Islander & \\
\hline Native American or Alaska Native & \\
\hline
\end{tabular}

2i. Does any clinician in your practice provide care in language other than English?

$$
\begin{aligned}
& \square \text { Yes, Spanish } \\
& \square \text { Yes, other } \\
& \square \text { No }
\end{aligned}
$$

If other, what language(s)?

2j. Does your practice use an electronic medical record (EMR)?

$\square$ Yes, all electronic

Yes, part electronic and part paper

No, all paper

$\square$ Don't know

If yes, what EMR does your practice use?

\section{Section 3: Medicaid Expansion Plans}

In January 2019, Virginia will expand Medicaid coverage to all adults with family incomes at or below $138 \%$ of the federal poverty line. The next set of questions asks about how Medicaid Expansion will affect your practice.

3a. After Medicaid Expansion, will your practice accept more Medicaid patients?

$$
\square \text { Yes }
$$

3b. When deciding whether or not to accept new

Medicaid patients, please indicate the importance of each of the following reasons for your practice's decision.

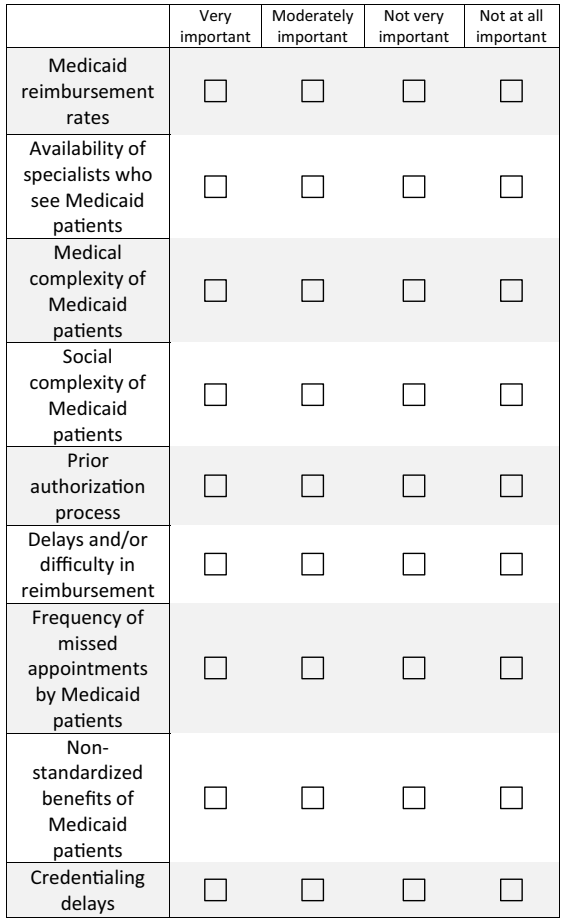

3c. What one improvement could Medicaid make to increase the likelihood of your practice accepting new Medicaid patients?

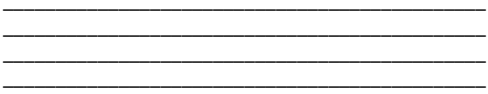

3d. Does your practice plan on making any changes to prepare for Medicaid Expansion?

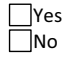


If yes, what changes?

$\square$ Hire more clinicians

$\square$ Hire more staff

Hire different provider types (e.g. social worker mental health provider)

$\square$ Extend hours

$\square$ Add new services

$\square$ other

If other, please specify:

Section 4: Practice Operations

4a. Practice ownership:

$\square$ Hospital/Health System

$\square$ Clinician Owner

$\square$ Clinician Partially Owned

$\square$ Private Sponsor/Corporation

$\square$ Insurance Company

University Owned

4b. Please provide your best estimate for what your practice's current payer mix is?

Please make sure the total adds up to 100

\begin{tabular}{|l|l|}
\hline & Percent (\%) \\
\hline Commercial or Private & \\
\hline Medicaid & \\
\hline Medicare & \\
\hline Uninsured & \\
\hline
\end{tabular}

4c. Is your practice currently accepting new patients with the following insurance types?

\begin{tabular}{|c|c|c|c|c|}
\hline & $\begin{array}{c}\text { Accept } \\
\text { ALL new } \\
\text { patients }\end{array}$ & $\begin{array}{c}\text { Accept } \\
\text { MOST } \\
\text { new } \\
\text { patients }\end{array}$ & $\begin{array}{c}\text { Accept } \\
\text { sOME } \\
\text { new } \\
\text { patients }\end{array}$ & $\begin{array}{c}\text { Accept } \\
\text { NO new } \\
\text { patients }\end{array}$ \\
\cline { 1 - 2 } $\begin{array}{c}\text { Commercial } \\
\text { or Private }\end{array}$ & $\square$ & $\square$ & $\square$ & $\square$ \\
\cline { 1 - 1 } Medicaid & $\square$ & $\square$ & $\square$ & $\square$ \\
\cline { 1 - 1 } Medicare & $\square$ & $\square$ & $\square$ & $\square$ \\
\cline { 1 - 1 } Uninsured & $\square$ & $\square$ & $\square$ & $\square$ \\
\hline
\end{tabular}

Section 5: Services Your Practice Provides

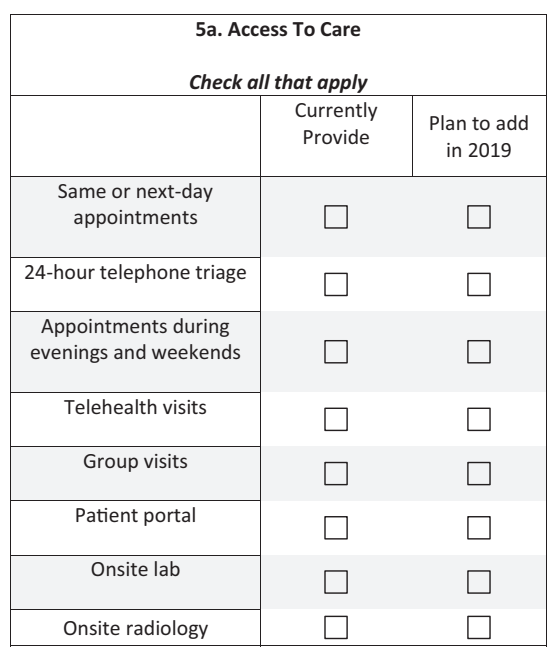

\begin{tabular}{|c|c|}
\hline \multicolumn{2}{|c|}{ 5b. Population Health } \\
Check all that apply \\
\hline & $\begin{array}{c}\text { Currently } \\
\text { Provide }\end{array}$ \\
$\begin{array}{c}\text { Plan to add } \\
\text { in } 2019\end{array}$ \\
\hline $\begin{array}{c}\text { Care coordination, } \\
\text { patient navigation, or } \\
\text { case management }\end{array}$ \\
\hline $\begin{array}{c}\text { Use of a registry or list to } \\
\text { identify patients in need } \\
\text { of care }\end{array}$ \\
\hline $\begin{array}{c}\text { Routine measurement of } \\
\text { quality or performance }\end{array}$ \\
\hline
\end{tabular}




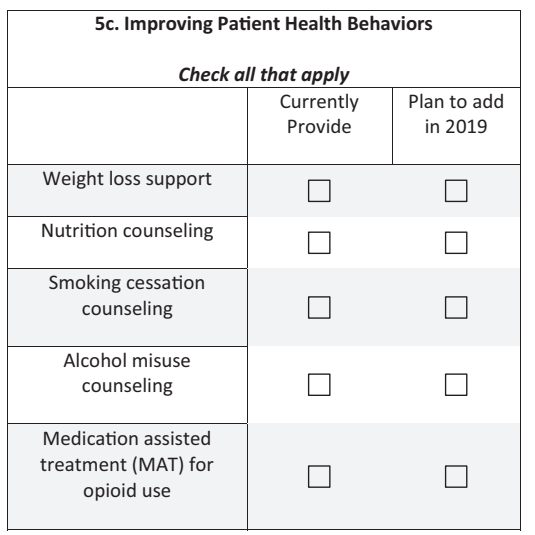

Section 6: Challenges Your Practice Faces

6a. Does your practice address the following patient needs?

\begin{tabular}{|c|c|c|c|c|}
\hline & $\begin{array}{l}\text { Yes, } \\
\text { address } \\
\text { in our } \\
\text { practice }\end{array}$ & $\begin{array}{c}\text { Yes, } \\
\text { refer to } \\
\text { health } \\
\text { system } \\
\text { resource }\end{array}$ & $\begin{array}{l}\text { Yes, refer } \\
\text { to } \\
\text { community } \\
\text { resource }\end{array}$ & $\begin{array}{c}\text { No, we } \\
\text { do not } \\
\text { address } \\
\text { this }\end{array}$ \\
\hline $\begin{array}{l}\text { Assistance with } \\
\text { out-of-pocket } \\
\text { medical costs }\end{array}$ & $\square$ & $\square$ & $\square$ & $\square$ \\
\hline Unemployment & $\square$ & $\square$ & $\square$ & $\square$ \\
\hline Health literacy & $\square$ & $\square$ & $\square$ & $\square$ \\
\hline $\begin{array}{l}\text { Unstable } \\
\text { housing }\end{array}$ & $\square$ & $\square$ & $\square$ & $\square$ \\
\hline Transportation & $\square$ & $\square$ & $\square$ & $\square$ \\
\hline Food Security & $\square$ & $\square$ & $\square$ & $\square$ \\
\hline $\begin{array}{l}\text { Safety issues } \\
\text { (e.g. intimate } \\
\text { partner } \\
\text { violence, } \\
\text { unsafe } \\
\text { community) }\end{array}$ & $\square$ & $\square$ & $\square$ & $\square$ \\
\hline $\begin{array}{c}\text { Social isolation } \\
\text { or loneliness }\end{array}$ & $\square$ & $\square$ & $\square$ & $\square$ \\
\hline $\begin{array}{c}\text { Health } \\
\text { behaviors (e.g. } \\
\text { diet, exercise, } \\
\text { weight loss) } \\
\end{array}$ & $\square$ & $\square$ & $\square$ & $\square$ \\
\hline $\begin{array}{l}\text { Opioid use } \\
\text { disorder }\end{array}$ & $\square$ & $\square$ & $\square$ & $\square$ \\
\hline $\begin{array}{c}\text { Non-opioid } \\
\text { substance use } \\
\text { disorder(s) } \\
\text { (e.g. alcohol, } \\
\text { illicit drugs, } \\
\text { etc.) } \\
\end{array}$ & $\square$ & $\square$ & $\square$ & $\square$ \\
\hline $\begin{array}{l}\text { Mental health } \\
\text { issues (e.g. } \\
\text { stress, anxiety, } \\
\text { depression, } \\
\text { trauma) }\end{array}$ & $\square$ & $\square$ & $\square$ & $\square$ \\
\hline
\end{tabular}


6a. The table below lists problems that may limit physicians' ability to provide high quality care. For each one, indicate whether you think it is a major problem, minor problem, or not a problem affecting your practice's ability to provide high quality care.

\begin{tabular}{|c|c|c|c|}
\hline & $\begin{array}{c}\text { Major } \\
\text { problem }\end{array}$ & $\begin{array}{c}\text { Minor } \\
\text { problem }\end{array}$ & $\begin{array}{c}\text { Not a } \\
\text { problem }\end{array}$ \\
\hline $\begin{array}{l}\text { Inadequate time } \\
\text { with patients } \\
\text { during office visits }\end{array}$ & $\square$ & $\square$ & $\square$ \\
\hline $\begin{array}{l}\text { Patients' inability } \\
\text { to pay for needed } \\
\text { care }\end{array}$ & $\square$ & $\square$ & $\square$ \\
\hline $\begin{array}{l}\text { Rejections of care } \\
\text { decisions by } \\
\text { insurance } \\
\text { companies }\end{array}$ & $\square$ & $\square$ & $\square$ \\
\hline $\begin{array}{c}\text { Lack of qualified } \\
\text { specialists in your } \\
\text { area }\end{array}$ & $\square$ & $\square$ & $\square$ \\
\hline $\begin{array}{l}\text { Not getting timely } \\
\text { reports from other } \\
\text { physicians and } \\
\text { facilities }\end{array}$ & $\square$ & $\square$ & $\square$ \\
\hline $\begin{array}{c}\text { Difficulties } \\
\text { communicating } \\
\text { with patients due } \\
\text { to language or } \\
\text { cultural barriers }\end{array}$ & $\square$ & $\square$ & $\square$ \\
\hline $\begin{array}{l}\text { Lack of necessary } \\
\text { resources to } \\
\text { address patient } \\
\text { mental health and } \\
\text { social needs }\end{array}$ & $\square$ & $\square$ & $\square$ \\
\hline
\end{tabular}

6c. Thinking about your practice specifically, how would you describe the competitive situation your practice faces?

(By competition among physicians, we mean the pressure to undertake activities to attract and retain patients)

$\square$ Very competitive

Somewhat competitive

$\square$ Not at all competitive 6d. Please indicate in which time period your practice has experienced and/or anticipates any of the following major changes.

Check all that apply

\begin{tabular}{|l|c|c|}
\hline & $\begin{array}{c}\text { In the past } \\
12 \text { months }\end{array}$ & In 2019 \\
\hline Move to a new office & $\square$ \\
\hline New medical records system & \\
\hline Change ownership & \\
\hline Office renovation & \\
\hline New billing system & $\square$ \\
\hline Significant clinician turnover & $\square$ \\
\hline Other & $\square$ \\
\hline If other, please specify: & $\square$ \\
\hline
\end{tabular}

$6 e$. What are the biggest challenges that your practice currently faces?

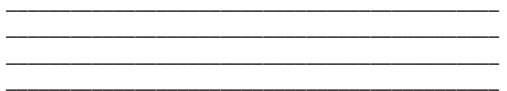

6f. What kind of innovative changes has your practice implemented to address these challenges?

\section{Interest in research}

Would you be interested in participating in research that matters to primary care?

$$
\square \text { Yes }
$$

$\square$ No

What kinds of research is your practice interested in participating? Please check all that apply

\begin{tabular}{ll}
$\square$ Burnout & $\square$ Chronic disease \\
\hline$\square$ Practice redesign & $\square$ Health behavior change
\end{tabular}

Informatics

Addressing social needs $\square$ Mental Health

If other, please specify:

Thank you for taking the time to answer this survey. Your information will help to make sure we continue to provide the best care for Virginians possible.

<<eycode〉> 